URBAN LEGENDS 



\section{URBAN LEGENDS}

THE SOUTH BRONX

IN REPRESENTATION AND RUIN

\section{Peter L'Official}

\section{III \\ II \\ Harvard University Press}

Cambridge, Massachusetts

London, England

2020 
Copyright ( 2020 by the President and Fellows of Harvard College All rights reserved

Printed in the United States of America

First printing

Jacket design: Jill Breitbarth

Jacket photo: JayLazarin/iStock/Getty Images Plus

9780674246485 (EPUB)

9780674246492 (MOBI)

9780674246515 (PDF)

The Library of Congress has cataloged the printed edition as follows:

Names: L'Official, Peter, 1980- author.

Title: Urban legends : the South Bronx in representation and ruin / Peter L'Official.

Description: Cambridge, Massachusetts : Harvard University Press, 2020. I Includes bibliographical references and index.

Identifiers: LCCN 2019056425 | ISBN 9780674238077 (cloth)

Subjects: LCSH: Urban folklore-New York (State)—New York. I Bronx (New York, N.Y.)—Civilization-20th century. I Bronx (New York, N.Y.)—In art. I Bronx (New York, N.Y.)-Social life and customs.

Classification: LCC F128.68.B8 L64 2020 I DDC 974.7/275—dc23

LC record available at https://lccn.loc.gov/2019056425 
For Sylvia Quiñones L’Official 
